\title{
Procedure for Radio Dating of Water Using Nuclear Hydrological Isotopes Techniques
}

\author{
Muhammad S.B. ${ }^{1}$ Nasiru R. ${ }^{2}$ Sumaila Y.A. ${ }^{1}$ \\ ${ }^{1}$ (Department of Physics, Umaru Musa Yar'adua University, Katsina, Nigeria.) \\ ${ }_{2}^{2}$ (Department of Physics, Ahmadu Bello University, Zaria, Nigeria)
}

\begin{abstract}
The regular rates of decay for unstable radioactive elements were found to constitute a virtual "clocks" within a material they are found to be component. Some water molecules are found to be radioactive due to the increase of tritium in the atmosphere. Tritium concentration in groundwater reflect atmospheric tritium levels when the water was last in contact with the atmosphere, therefore, any measurable tritium concentrations in groundwater system provides clear evidence of recharge occurring into the system during the last four decades. Since 1970s, the atmospheric tritium concentration has decreased. Thus, the presence of excess tritium in groundwater indicates recharge on a time scale of approximately 60 years. Samples are collected along with geographical coordinate of the sampling point. The samples are collected from precipitation, surface water and groundwater which undergo three stages of tritium analysis viz: Screening, Tritium enrichment (Electrolysis) and Scintillation counting. Tritium activity $A_{B}$ in $[\mathrm{Bq} / \mathrm{Kg}]$ and tritium concentration $A_{T}$ in [TU] are related as:
\end{abstract}

$A_{T}=\frac{A_{B}}{0.118}[T U]$.

Keywords: Tritium, Radio-dating, Tritium unit (TU), thermonuclear explosion, Atmosphere, Radioactive elements,

\section{Introduction}

All matter is made up of combination of chemical elements, each with its own atomic number, indicating its properties. Moreover, elements may exist in different isotopes, with each isotope of an element differing in the number of neutron in the nucleus. An isotope of a particular element is called a nuclide. Some nuclides are inherently unstable. Thus at some point in time, an atom of such a nuclide will undergo radioactive decay and spontaneously transform into a different nuclide. The moment in time at which a particular nucleus decays is unpredictable, a collection of atoms of radioactive nuclide decays exponentially at rate described by a parameter known as half-life, which is normally express in units of years in dating techniques. After one half-life has elapsed, one half of the atoms of the nuclide in question will have decayed into a" daughter" nuclide. This trend continues and results in a decay chain, eventually ending with formation of a stable nuclide. Therefore, each step in such a chain is characterized by distinct half-life.

Water, being a matter, consists of various isotopes of which most frequently occurring are those of hydrogen $(\mathrm{H})$ and oxygen $(\mathrm{O})$, while a smaller fraction consist of their rare isotopes of deuterium( $\mathrm{D})$, tritium (T) and Oxygen eighteen $\left({ }^{18} \mathrm{O}\right)[1,2,3]$. All of these isotopes are stable except tritium $(\mathrm{T})$ which is radio isotope with half-life of $12.32 \mathrm{yrs}$.

Tritium is produced naturally in the Earth's atmosphere, though its main use in hydrology stems from its production in large quantities by atmospheric testing of thermonuclear bombs. During this period, artificial tritium of $236 \times 1018 \mathrm{~Bq}$ was released into the earth [4], which amounts to about 181 times higher than that of natural tritium in the earth. Since 1952, tritium contents of precipitation and groundwater increased and reached a peak in 1963. Tritium activities in continental precipitation prior to the advent of nuclear weapons testing in 1952 were in the range of 1 to 20 TU's [1]: tritium concentration in surface water on land is found to be 2-8TU $(0.2-0.9 \mathrm{~Bq} / \mathrm{L})$ whereas $1 \mathrm{TU}(0.1 \mathrm{~Bq} / \mathrm{L})$ in the surface ocean. In late 1963 , a moratorium on atmospheric testing was declared, and tritium activities in precipitation have decreased since then to pre-1953 levels. Tritium is thus used as an indicator of pre-1953 or post-1953 recharge of groundwater. The case of absence of tritium, however, could be indicative of either recharge not being significant during the above-cited period, or the travel times involved in the systems being longer than the time required for the decay of the isotope during its transport [5]. The tritium content of water is expressed in tritium units (TU). One tritium unit is defined as one atom of ${ }^{3} \mathrm{H}$ per 1018atoms of hydrogen, which is equivalent to a specific activity of $0.118 \mathrm{~Bq} / \mathrm{L}$ or $3.19 \mathrm{pCi} / \mathrm{L}$ of water. 


\section{Material and Method}

Tritium concentration in river water and groundwater increased after the beginning of thermonuclear test and becomes larger than that of precipitation after the end of aerial thermonuclear tests. In groundwater, tritium concentration can be varied from place to place even in a small area. The formation rate of tritium depends on cosmic rays produced by neutron flux. The neutron flux is four times greater in the polar region than in the equatorial region [6]. Therefore, tritium concentration is higher in higher latitudes even after the artificial tritium has disappeared. Groundwater dating based on tritium uses the fact that the initial concentration $\mathrm{A}_{0}$ (expressed in TU) in recharging groundwater decreases with time according to the decay equation

$$
\boldsymbol{A}_{t}=\boldsymbol{A}_{o} \mathrm{e}^{-\lambda t}
$$

Where A ( $t$ ) is the tritium concentration measured in a sample after decay over time $t$ and $\lambda$ is the decay constant.

\subsection{Sample collection}

The samples are collected monthly or annually depending on the time available for the research and precision aim by the researcher. Latitude, longitude, altitude and instiu temperature of the sampling points are dully recorded. The water samples are collected in a high-density polyethylene bottle and stored in dark room at room temperature. The geology and hydrological data of the area are required. The chemical analysis of the sample water is also necessary.

\subsubsection{Precipitation sampling}

The precipitation sample is usually collected during the rainfall by attaching funnel to the high-density polyethylene bottle which is kept on a plain land at an open space during the rain and before the rain stops completely the bottle is unscrewed from the funnel and immediately sealed with a plastic cone cap.

\subsubsection{Surface-water sampling}

The sample of unfiltered, unacidified Surface water is collected from random selected dams, rivers, lakes and ponds. This is done after the water is well stirred so as to get a true isotopic representative of the surface water aquifer in the sample water and immediately a high-density bottle is deep into the water filled up and closed from inside the water in order to avoid fractionation.

\subsubsection{Groundwater sampling}

The sample of unfiltered, unacidified groundwater is collected from random selected hand-pump motorized boreholes that are in continuous abstraction and whose depth, location and hydraulic information is known. The samples are collected after pumping for about 5 minute if water is not already being pumped prio to arrival at the pump site. This is to purge the boreholes of stagnant water around the pump parts, so that the water sample is isotopic representative of the aquifer.

\subsection{Tritium Fundamentals}

The radioactive isotope of hydrogen, ${ }^{3} \mathrm{H}$, naturally originates from a nuclear reaction between atmospheric nitrogen and thermal neutrons in the upper atmosphere [7]:

$$
\begin{aligned}
& { }^{14} \mathrm{~N}\left(\mathrm{n},{ }^{12} \mathrm{C}\right) 3 \mathrm{H} \\
& { }^{2} \mathrm{H}(\mathrm{n}, \text { gamma ray }){ }^{3} \mathrm{H}
\end{aligned}
$$

The ${ }^{3} \mathrm{H}$ thus formed naturally and bomb tritium enters the hydrologic cycle after oxidation to ${ }^{1} \mathrm{H}^{3} \mathrm{HO}$, it reaches the surface of the earth as part of rain water, in which it is essentially a conservative tracer. Production rate of natural tritium in the atmosphere is estimated to be 2500 atoms $/ \mathrm{m} 2 / \mathrm{s}$ (troposphere: 840 , stratosphere: 1660)[8]. Tritium finally decays according to the equation:

$$
{ }^{3} \mathrm{H} \rightarrow{ }^{3} \mathrm{He}+\boldsymbol{\beta}-
$$

with $E_{\beta \max }=18 \mathrm{KeV}$ and half-life of 12.32 years.

The experimental analysis of Tritium is carried out in three stages viz:

- Screening,

- Electrolysis

- Scintillation counting.

\subsubsection{Screening}

Water samples for tritium analysis are distilled in order to remove particles and purify it of all forms of dirtiness. Thus an initial screening of the tritium concentration is carried out. This step can be left out, if water with known environmental tritium concentration, i.e. well $>100 \mathrm{TU}$, is sampled. $10 \mathrm{ml}$ of the sample are mixed with $11 \mathrm{ml}$ Ultima Gold liquid scintillator in a counting vial. The samples are then placed in the Packard Tri- 
Carb 2770TR/SL. Low-Level liquid scintillation analyzer, and counted for at least three cycles of four hours. Samples found with tritium concentration of less than 100TU are subsequently enriched by electrolysis.

\subsubsection{Electrolysis}

Electrolytic enrichment of tritium more than 10 times is recommended prior to the measurement by a liquid scintillation counter. A volume of some $500 \mathrm{mil}$ of the screen sampled water is mixed with four gram of sodium peroxide and introduced into the electrolytic cell. A direct current of some 5-10 ampere at 12V is passed through the cell, which is cooled because of process heat generation. After several days (at least five days), the electrolyte volume is reduced to some 20 mil. This volume reduction of 25 times produces a corresponding tritium enrichment factor of about 20. Samples of standard known tritium concentration (spike) are run in one cell of each batch to check on the enrichment attained. The screen sampled water is electrolyzed to hydrogen and oxygen, tritium, the heaviest isotope of hydrogen, strongly enriches in water phase rather than in hydrogen gas, therefore, tritium separation factor between water and hydrogen is highly significant[3].

\subsubsection{Counting}

To measure tritium, it is recommended to use a low-background type liquid scintillation counter, which is equipped with an anti-coincident counter, and lead shield that largely reduces background of cosmic ray and other form of radiation. For liquid scintillation counting, the enriched water sample is directly distilled (vacuum distillation) from the now highly concentrated electrolyte. A ten mil volume of the vacuum distilled water sample is mixed with eleven mil $(11 \mathrm{ml})$ Ultima Gold cocktail in a counting vial. The sample is then placed in the Packard Tri-Carb 2770TR/SL Low-Level liquid scintillation analyzer and counted for 2-3 cycles of 4 hours [9]. Detection limits are $0.2 \mathrm{TU}$ for enriched samples.

\subsubsection{Calculation of Tritium Content in Water}

1. Calculation of Counting Efficiency (C.E.)

The activity of the standard solution at the midpoint of counting time $(\mathrm{dpm} / \mathrm{ml})$ is determined as follows:

- The standard solution has a certain activity at the date of its preparation but this activity changes with time due to the radioactive decay phenomena [10]. Therefore, the time between the date of preparation of the standard solution and midpoint of counting date is computed.

- The decay factor used was $e^{-\lambda t}$

Where

$$
\lambda=\operatorname{In}\left[\frac{2}{T_{1 / 2}}\right]
$$

$$
T_{1 / 2}=\text { half- life of tritium }=12.32 \text { year, } \mathrm{t}=\text { midpoint of counting. }
$$

The net counts per minute for samples-blanks and standard solution after electrolytic enrichment step is determined as follows:

$(\text { net cpm })_{\text {sample or standard }}=(\text { average cpm })_{\text {sample or standard }}-(\text { average cpm })_{\text {background }}$

The net $\mathrm{cpm}$ per $\mathrm{ml}(\mathrm{net} \mathrm{cpm} / \mathrm{ml})$ for samples-blanks and standard solution after the enrichment step is determined by using the following formula:

$$
\text { net } \mathrm{cpm} / \mathrm{ml}=\frac{(\text { net } \mathrm{cpm})_{\text {sample or standard }}}{\text { volume of sample counted }(\text { normally } 3 \mathrm{ml})}
$$

The counting efficiency (C. E.) is calculated as follows:

$$
\text { C.E. }=\frac{(\text { net } c p m)_{\text {standard }}}{\text { Activity of standard solution }} \times 100
$$

The net $\mathrm{cpm} / \mathrm{ml}$ for all samples-blanks and standard solution taking part in the enrichment step is determined as follows:

$$
\text { net } \mathrm{cpm} / \mathrm{ml}=\frac{(\text { net } \mathrm{cpm} / \mathrm{ml})}{C . E .} \times 100
$$

The electrolysis efficiency of each standard solution (E.E. standard) taking part in the enrichment step is calculated using the following equation:

Where

$$
\text { E.E. }=\frac{d p m / m l}{d p m_{o} / m l} \times \frac{V}{V_{o}}
$$

$$
\begin{gathered}
d p m_{o} / m l=\frac{(\mathrm{dpm} / \mathrm{ml})^{*} \text { standard solution } \times \text { volume of standard used }}{V_{o}} \\
V_{\mathrm{o}}=\text { initial volume before enrichment }=250 \mathrm{ml} \\
\mathrm{V}=\text { final volume after enrichment }
\end{gathered}
$$

The volume of the standard used is $1 \mathrm{ml}$, which is added to $249 \mathrm{ml}$ of tritium-free water (dead water). This dead water is obtained from the Western Desert Oasis known to have no tritium. 
The enrichment factor, B, for each standard solution cell, which took part in the enrichment step, is calculated as follows:

$$
B=-\left[\frac{\log \frac{V}{V_{o}}}{\log E \cdot E_{\cdot \text { standard }}}\right]
$$

The average enrichment factor $\left(\mathrm{B}^{*}\right)$ for three standard solutions is determined. The Electrolysis Enrichment Efficiency of each water sample of unknown tritium content is calculated as follows:

$$
\log E . E_{\text {Sample }}=\frac{-1}{B^{*}} \log \frac{V_{o}}{V}
$$

$(\mathrm{dpm} / \mathrm{ml})$ for each sample and unknown tritium content is calculated as follows:

$$
\left(d p m_{o} / m l\right)_{\text {Sample }}=\frac{(d p m / m l)_{\text {Sample }}}{E \cdot E_{\text {Sample }}} \times \frac{V}{V_{o}}
$$

The concentration of tritium expressed as T.U. for each water sample is determined as follows:

$$
\text { T.U. }=\frac{\left(d p m_{o} / m l\right)}{0.0072}
$$

The tritium activity of natural water samples is usually expressed in terms of tritium unit;

$$
\begin{aligned}
1 \mathrm{~T} . \mathrm{U} .= & 1 \text { tritium atom } / 10^{18} \text { hydrogen atom, or } \\
& 1 \mathrm{~T} . \mathrm{U} .=7.2 \mathrm{dpm} / 1=0.0072 \mathrm{dpm} / \mathrm{m}
\end{aligned}
$$

\section{Data processing}

Data processing refers to the entering, storing, updating and retrieving of information using a computer. This must be organized depending on how and when the data is collected with reference to a standard method provided by International atomic energy agency (IAEA). This will greatly help in data treatment which will subsequently yield a better result.

\subsection{Data treatment}

\subsubsection{Weighted mean}

The weighted mean values are computed as

$$
\overline{\delta_{w}}=\frac{\sum_{i=1}^{n} P_{i} \delta_{i}}{\sum_{i=1}^{n} P_{i}}
$$

Where $P_{i}$ and $\delta_{i}$ denote the monthly precipitation and its delta value and $\mathrm{n}$ represent number of available data for each month [11].

The annual means for tritium, deuterium, oxygen-18 and deuterium excess weighted by the amount water (precipitation) should be calculated. For the stable isotopes, also the total weighted means should be calculated. Total weighted means and amount of precipitation, excluding months with precipitation lower than or equal to $20 \mathrm{~mm}$, should be computed. Monthly weighted means values and standard deviations should also be computed for stable isotopes [11].

\subsubsection{Correlations}

Two methods of linear correlation between sets of data are applied: the least- squares regression and the reduction major axis line [11].

\section{Conclusion}

Tritium provides information about groundwater's age (Mean residence time), which refers to the last time the water, was in contact with the atmosphere. Tritium decays to ${ }^{3} \mathrm{He}$ with a half-life of 12.32 years. The amount of ${ }^{3} \mathrm{He}$ from the decay of tritium $\left({ }^{3} \mathrm{H} \rightarrow{ }^{3} \mathrm{He}+\boldsymbol{\beta}-\right)$ is measured along with the amount of tritium remaining in the water to give the mean residence time of the water. Since the sum of tritium decay and tritium remaining in the water is equal to the amount of tritium that was present at the time of recharge. The ${ }^{3} \mathrm{H}-{ }^{3} \mathrm{He}$ dating method is remarkably accurate for groundwater up to 60 years old with an age resolution of plus or minus one year [1, 11, and 12].

\section{References}

[1] Yurtsever, Y. and Araguas, L. A. (1993). Environmental isotope applications in hydrology: An overview of the IAEA's activities, experiences, and prospects. Proc. of the Yokohama Symp. July 1993. IAHS Publ. No. 215

[2] Gudmundsson,K (2000).Isotopic tracing of moisture in buildings.Nordic Journal of Building Physics, Vol.2pp22

[3] International Hydrological Progrmme (2001). 11th International Course on Hydrogen and Oxygen Isotopes in Hydrology. ISBN: 49980619-3-3, Nagoya University COOP

[4] United Nations Scientific Committee on the Effects of Atomic Radiation (1982). 1982 report on "Ionizing radiation: sources and biological effects", United Nations, New York.

[5] Nair, RA.,Pendharkar, A.S. Navada,S.V.and Rao,S.M.(1979)Groundwater studies in Matrashtra. Development of isotope techques and field experience. Proc.Symp.Isotope Hydrology, 19-23 June 1978, Neuherberg, IAEA, Vienna 803-826 
[6] Fontes, J.C.( 1980). Environmental isotopes in groundwater hydrology. Handbook of environmental isotope geochemistry, 75-140, Elsevier, Amsterdam.

[7] Libby, W. F. (1946). Atmospheric helium-3 and radiocarbon from cosmic radiation. Phys. Rev. 69: 671-672.

[8] United Nations Scientific Committee on the Effects of Atomic Radiation (1982). 1982 report on "Ionizing radiation: Sources andbiological effects", United Nations, New York.

[9] Pakard instrument company(1995). Tri-Cab Liquid scintillation Analyzerrs: models 2100TR/2300

[10] Franz,s. (1995). Liquid Scintillation Spectrometry in environmental measurements. The science of the Total Environment $173 / 174 ; 29-40$

[11] Clark, I.D. and Fritz, P. (1997). Environmental isotopes in hydrology. Lewis Publishers, New York, 328p.

[12] International Atomic Energy Agency (1981). Statistical treatment of environmental isotope data in Precipitation. Technical Report Series No. 206. STI/DOC/10/206. 